
\title{
25 Research Square \\ Determinants of adolescent pregnancy among adolescents in Wakiso and Kamuli Districts in Uganda; a case control study
}

Nabukeera-Barungi Nicolette ( $\square$ nicolettebarungi@gmail.com )

Makerere University College of Health Sciences

\section{Piloya-Were Theresa}

Makerere University College of Health Sciences

\section{Namusoke Fatuma}

Makerere University College of Health Sciences

Rujumba Joseph

Makerere University College of Health Sciences

Namiiro Flavia

Mulago National Referral Hospital

\section{Oriokot Lorraine}

Makerere University College of Health Sciences

Mubiri Paul

Makerere University College of Health Sciences

\section{Bakeera-Kitaka Sabrina}

Makerere University College of Health Sciences

\section{Research Article}

Keywords: Adolescent, Pregnancy, determinants, rural, urban

Posted Date: February 25th, 2022

DOl: https://doi.org/10.21203/rs.3.rs-1359438/v1

License: (a) (i) This work is licensed under a Creative Commons Attribution 4.0 International License. Read Full License 


\section{Abstract \\ Background:}

Uganda has unacceptably high teenage pregnancy rates whereby 1 in 4 adolescent girls have been pregnant by 18 years. This has social, financial and health consequences for the adolescents, their children and the whole society. It is therefore important to identify the adolescents at highest risk so that they can be targeted with interventions to reduce teenage pregnancy. Our study aimed to determine risk factors for pregnancy among adolescents in one rural and one urban district in Uganda.

\section{Methods}

We conducted a mixed-methods study among girls aged 13 to 19 years in a rural and urban district in Uganda. Quantitatively, we used an unmatched case control design where cases were 200 adolescents who were currently or previously pregnant while 400 controls were adolescents who had ever experienced a pregnancy. The 600 were divided equally between the 2 districts. Quantitative data was analyzed using STATA version 14 . Qualitative methods included 17 focus group discussions with adolescents and their parents, 10 in-depth interviews with adolescents and 20 key informant interviews with various key stakeholders. Audio recordings were transcribed and analyzed using a content thematic approach using Nvivo.

\section{Results}

Of the 600 girls, mean age was 16.9 years (SD 3.84), 57.6\% were not in a sexual relationship and $75.3 \%$ were inschool. Independent risk factors for adolescent pregnancy were age; AOR 1.69 (95\% Cl; 1.48-1.95), out-of-school AOR $6.13(95 \% \mathrm{Cl} 2.91-12.92)$, a friend with pregnancy AOR 1.91 (95\% Cl; 1.23-2.96), cigarette smoking experience AOR 6.68 (1.42-31.46), working for money AOR 1.70 (1.05-2.74) and correct contraceptive knowledge AOR 1.32 (95\% Cl; 1.13-1.54). Protective factors included positive personal attitudes, higher education of the father and larger household size.

\section{Plain English Text}

Uganda has unacceptably high teenage pregnancy rates whereby 1 in 4 adolescent girls have been pregnant by 18 years. This has social, financial and health consequences for the adolescents, their children and the whole society. We aimed to determine which teens are at higher risk for pregnancy in one rural and one urban district in Uganda.

We conducted a study among girls aged 13 to 19 years in a rural and urban district in Uganda. Of the 600 girls, 200 had pregnancy experience while 400 had ever experienced a pregnancy. The 600 were divided equally between the 2 districts. We interviewed all the 600 adolescents using questionnaires. In addition, we had some open-ended discussions with other adolescents, their parents and other stakeholders.

The mean age was 16.9 years, $57.6 \%$ were not in a sexual relationship and $75.3 \%$ were in-school. Adolescents who were at risk of pregnancy included those who were older in age, out-of-school, those who had a friend with 
pregnancy, cigarette smoking experience, those working for money and having correct contraceptive knowledge. Protective factors included positive personal attitudes, higher education of the father and larger household size.

Additional factors from the open discussions included; inadequate information on sexual and reproductive health, early sexual debut, alcohol and drug abuse, absence of parental supervision, negative peer influence and poverty.

Keeping girls in school and poverty reduction remain key strategies of prevention of teen pregnancy. Knowledge of contraceptives alone is not enough to prevent teen pregnancy.

\section{Background}

Adolescents are particularly vulnerable to sexual exploitation and high-risk behaviours which may result in pregnancy. A World Health Organisation report in 2014 put the global adolescent birth rate at 49 per 1000 girls aged 15 to 19 years (WHO, 2014). Adolescent pregnancy in Africa and sub-Saharan Africa was 18.8\% and 19.3\% respectively (Kassa GM, Arowojolu AO, Odukogbe AA, Yalew AW, 2018). In Uganda, the prevalence of teenage pregnancy is reported to remain high at $25 \%$ as the national prevalence rate (UBOS, 2017). The highest rates of adolescent pregnancy in Uganda are reported in the East Central region at $30.6 \%$ with rural teenagers having higher rates than their urban counterparts (UBOS, 2012). Adolescent pregnancy is a major public health and social problem which has implications on the educational opportunity, population growth and health of women.

Factors that promote adolescent pregnancy at the community level include traditional cultural norms and perceptions about the definitions of childhood and transition to adulthood. In addition, modernization of many communities with increased entertainment spaces for adolescents increases vulnerability to adolescent pregnancy. Other risk factors for teenage pregnancy include family and individual characteristics of the adolescents (Yakubu I \& Salisu WJ, 2018).

Adolescent pregnancy results in various health complications for them and their infants, risk of stopping education (Mpyangu CM, 2014), early marriage, a lifetime cycle of poverty and deaths from pregnancy-related conditions (UBOS, 2017). Dropping out of school puts them into the cycle of poverty and this affects attainment of SDG 1 which calls for an end to poverty in all its manifestations by 2030. It is therefore paramount that we develop interventions aimed at reducing adolescent pregnancy rates.

Despite several efforts, adolescent pregnancy increased from 24-25\% between 2011 and 2016 (UBOS, 2012, 2017). Moreover, the current average rate of reduction in teenage pregnancies is so slow at $3 \%$ per year over the last 10 years. The $14 \%$ target of adolescent pregnancy by the Ugandan Ministry of Health $(\mathrm{MoH}$, Uganda, 2016) may not be achieved unless there are efforts to accelerate the current reduction rate. We therefore set out to determine the risk factors for pregnancy among adolescents in Wakiso and Kamuli districts, an urban and rural district respectively.

\section{Methods}

\section{Study design and setting}


A concurrent mixed methods design utilizing both quantitative and qualitative data generation methods was used in this study. Quantitatively, we used an unmatched case - control design to determine the risk factors of pregnancy among adolescents in the rural and urban communities. Cases were currently pregnant or those who experienced adolescent pregnancy. Controls were non-pregnant adolescents aged 13-19 years. We used in-depth interviews (IDI), focus group discussions (FGD) and key informant interviews (IDI) to explore risk factors for pregnancy.

The study was conducted in 2 districts (Wakiso and Kamuli districts). Wakiso district is situated in the central region of Uganda where it encircles Kampala, the capital city. Wakiso comprises 2 counties, 17 sub counties, 135 parishes and 1740 villages. Wakiso has a population of $2,735,100$ people, $75 \%$ of this population in the district is urban. Approximately, $17.3 \%$ of this population is made up of adolescents ages 10-17 years (UBOS, 2014). In 2014, the housing census data for Wakiso showed females aged 6-15 years with non-school attendance at $9 \%$ while those illiterate $10-17$ years was at $12.7 \%$. In addition, females $10-19$ years who had ever been married and those who had ever given birth were at $10.9 \%$ and $14.7 \%$ respectively (UBOS, 2014).

Kamuli district is located in the eastern region of Uganda. It has 13 sub-counties, 72 parishes and 1061 villages. The Kamuli district population in 2014 was 486,319 . Approximately, $28 \%$ of these are adolescents (10-19 years). Data from census in 2014 showed females ages 10-17 years not attending school were $6.9 \%$ and illiterate persons $10-17$ years were $20.1 \%$. Females aged 10-19 years who had ever been married and given birth were 12.7 and $15.8 \%$ respectively (UBOS, 2014). Kamuli district is located in the region with one of the highest adolescent pregnancy rates in Uganda at $30 \%$ (UBOS, 2012) and $27 \%$ of rural adolescents were child-bearing compared to $19 \%$ among urban dwelling adolescents (UBOS, 2017).

\section{Study Population}

The study population included adolescent girls aged 13-19 years residing in Wakiso and Kamuli district. Cases included girls who were pregnant at the time of the study or were previously pregnant. Controls were girls in the same age bracket who had never been pregnant. For the qualitative design, we included adolescents, their parents/guardians, school teachers, health workers and other stakeholders in the same districts.

The sample size was determined based study on predisposing factors of teenage pregnancy in Uganda (Tuyiragize R, 2018). This study found the probability of exposure among adolescent/teens who did not have knowledge of their ovulation cycle of $20.2 \%$ and odds ratios of exposure among adolescent that had knowledge of their ovulation cycle of 2.24 Using results from this study, we calculated the required sample size setting $a=5 \%$ level of significance ( $95 \%$ certainty) and power of $80 \%(\beta=0.2)$ for two controls per case, to be 100 cases and 200 controls. A total of 600 adolescents were interviewed (300 per district).

It should be noted that the sample size for the qualitative part of the study was indicative and in line with qualitative research guidelines, interviews continued until when additional interviews did not generate new information.

\section{Sampling procedure}

A two-stage cluster sampling approach was employed to select participants for quantitative component of the study. In the $1^{\text {st }}$ stage of sampling districts were divided into clusters. 
In the $2^{\text {nd }}$ stage, within each district, a probability proportional to size (PPS) sampling of 20 villages or enumeration areas (clusters) were taken.

In each district, an up-to-date list of villages or enumeration areas with their sizes (number of households in each) was obtained. PPS was done in Stata to obtain 20 clusters/villages for each district. Each cluster was visited and with help Local leaders and village health team (VHT) and a systematic sample of 10 households was taken. Within each sampled cluster (village), 15 adolescents were selected of whom 5 were pregnant and 10 non-pregnant (controls). The controls were sampled using systematic random sampling. From the centre of the village, every $5^{\text {th }}$ house was visited by research assistants who took opposite directions. If they did not have an eligible adolescent, the next house was taken until an adolescent was enrolled. Cases were identified by the VHTs probing the pregnancy status of all the adolescent girls, asking the health facilities in the community, parents and community leaders. Five of the pregnant girls identified from each village were randomly selected as cases.

Respondents of the qualitative design were purposively selected with the help of VHTs and health facilities in the communities that were visited. All qualitative interviews and discussions were audio recorded and transcribed.

\section{Data collection}

Data collection took three weeks starting in June 2020 amidst the COVID 19 pandemic. The country was under partial lock-down and all schools were closed. With the help of the VHTs and local village leaders, the research assistants approached the community members. Once in a selected household, the interviewers asked to speak to the selected respondent/adolescent, provided an explanation about the survey and obtained written informed consent for those aged 18 years and above before the survey proceeded. If the respondent was under 18 years, parental consent was sought and assent was obtained from the adolescent before enrolment of the adolescents.

The dependent variable was adolescent pregnancy. Independent variables included socio-demographic variables like age of the girl in years, tribe/ethnicity, religion, school status and level of education, birth order, place of residence (classified as urban or rural). Other independent variables included parental educational level, marital status, parental occupation, parenting style and socioeconomic status. This was assessed using ownership of household properties and was categorized as; rich, moderate and poor. We also collected data on Sexual and Reproductive Health (SRH) knowledge, behaviour and attitudes of adolescents. These variables were collected using a quantitative structured questionnaire which was administered by trained youthful study interviewers. Data collection involved household-based survey in which the interviews were administered on a one-to-one basis and in privacy in order to individualise the responses and to enhance their validity.

Qualitative data collection took place at the health facilities, offices of KII respondents or open general areas like the local leaders' residence. Qualitative methods of data collection included FGDs, KIls and IDIs which were conducted using appropriate guides with open ended questions to generate discussion. We conducted FGDs for various categories of adolescents in order to encourage free participation. In addition, we conducted FGDs for parents/caregivers in each of the 2 districts. FGDs took place at the selected health facilities. These were conducted by the investigators or research assistants. We observed FGD norms whereby the discussions were 
guided by an FGD guide, a moderator and an observer who took additional notes. Anonymity was maintained and confidentiality was ensured. The duration of FGD was about one and a half hours and discussions took place in the appropriate local languages. The discussions were audio recorded and later transcribed into English.

In-depth interviews were conducted with adolescents in order to gain more in-depth understanding of the sensitive SRH issues of adolescents. These may not be completely expressed in the FGDs due to their sensitive and private nature. IDI participants comprised of pregnant or lactating adolescents, any who used health services for STI screening and treatment, HIV testing or contraceptive services. Mobilization of the adolescents for IDI was done with the help of the village local leaders especially youth leaders, VHTs or health workers at the facilities.

The key informants comprised of various stakeholders including donor community, adolescent health implementing partners, district and community leaders, health workers, counselors, village health team members and teachers. The sample size was not static as qualitative interviewing continues until saturation. The PI, Co-PI and research assistants conducted the interviews at places that are convenient for the respondents. They took about 30-45minutes each and were all audio recorded.

\section{Data analysis and management}

All data collection was supervised by the investigators. Daily study meetings were held between the research assistants and the supervisors to review the data collection methodology and to resolve any logistical or methodological issues. Research assistants were taken through classroom training for 2 days. Training included adolescent $\mathrm{SRH}$, protocol training, quantitative and qualitative data collection techniques. This was followed by pilot testing of all the tools. Participating in pilot training was also a means of training the research assistants.

Data was entered using Epi Info and later transferred to Stata V.15 for analysis. Frequencies, proportions and totals were used to summarize categorical data while means, standard deviations and medians with interquartile ranges for continuous variables. All continuous variables were tested for normality. Crosstabulations by district and test for differences were done using various appropriate statistical tests. We used the mantel-hansel and conditional logistic regression model to determine risk factors at univariate and multivariable analyses. Factors with $\mathrm{p}$ value $\leq 0.2$ were considered for multivariate analysis using linear or poisson models. All models were tested for multicollinearity. Missing data was not replaced.

A relative wealth index was constructed using principal component analysis from a set of seven questions relating to household assets such as type of material of the floor, type of material for the roof, walls, ownership of household assets, domestic animals, water, electricity, TV and Radio. The index was divided in quintiles (Filmer D \& Pritchett LH, 2011).

Qualitative analysis started with transcription of the audio recordings. Transcripts from FGDs and IDIs in local languages were translated to English. Once all transcripts were in English, a codebook with code definitions and a data analysis plan was developed before the coding exercise started. The various codes were then grouped into categories and themes based on the objectives of the study. Transcripts were then exported into Nvivo 11 for electronic coding and analysis using content thematic approach (Graneheim UH \& Lundman B, 2004) and guided by the Social Ecological Model (SEM) model (Sallis JF et al., 2015; Stokols D, 1996) to locate risks of 
adolescent pregnancy in Uganda. Quotes to support the codes was put under each of the codes. The codes were combined into broader themes. The resultant themes were displayed and compared across study groups (adolescents, caregivers and key informants) through text descriptions and matrixes. A summary description of emerging themes, making use of key quotations, cases and explanations were used in writing this manuscript.

\section{Ethical review and approval process}

Ethical approval was sought from Makerere University College of Health Sciences; the School of Public Health Research and Ethics committee (REF HDREC 768). We then obtained approval from the Uganda National Council of Science and Technology (SS 5236), followed by permissions from the District Health Officers of Wakiso and Kamuli. We also obtained written consent/ assent from all study participants.

\section{Results}

\section{Sociodemographic characteristics of the adolescents}

Our study involved 600 girls whose mean age was 16.9 years (SD \pm 3.84 ). To note, $9.7 \%$ were married or separated at the time of the study and $75 \%$ were school-going. Other baseline characteristics of the adolescents are summarized in table 1 and 2 .

\section{Family and Household Characteristics}

Table 3 describes the baseline household and family characteristics of the 600 girls that participated in the study. The mean household size was 7.6 ( \pm SD 5.06) and the mean number of adolescents aged 10-19 years in the households was $3.2( \pm 3.01)$. Of the 600 adolescents, only $81(9.3 \%)$ had fathers with highest education level of Advanced- level and above, $72(14 \%)$ had fathers who had completed Ordinary -level education and 110 $(24 \%)$ had fathers with no education at all. Also, 142 (31\% had mothers with no education at all while only 52 (3.3\% had mothers who had A-level education and above and only 96 (13.7\%) of mothers had completed 0 -level education. Most of the adolescents; $\mathrm{N}=288$ (59\%) belonged to large family sizes of 7 and above. The social economic status was nationally representative. We had 240 (42\%) categorized as poor, $239(37 \%)$ as moderate and $119(22 \%)$ as rich according to a scoring system which was different for rural and urban dwelling adolescents.

Only $282(42 \%)$ reported ever having discussed sex with their parents. Of the 600 adolescents, $240(43 \%)$ reported their parents' parenting styles as being Disciplinarian/Authoritative, $249(37 \%)$ reported their parents as being permissive or liberal.

\section{Behaviour and experiences of adolescents}

We also described the behaviours and experiences of adolescents which affect adolescent pregnancy and table 4 has a summary of the findings. From the 200 girls who had ever been pregnant, the mean number of pregnancies was 1.1 (SD 0.64) and mean age of first pregnancy was 16.6 years.

Over $60 \%(\mathrm{~N}=337)$ had ever had sex and the mean age of first sex was 15.2 years while the average age of the sexual partner was 18.2 years. Most of them $\mathrm{N}=300(89 \%)$ reported that they consented to having sex the first 
time, but less than half; $47 \%(\mathrm{~N}=139)$ used condoms. From the $\mathrm{N}=132$ in Wakiso district who were sexually active, the average number of sexual partners was 1.8 people. (This data was not collected in Kamuli district).

\section{Bivariate analysis of Risk Factors of Adolescent Pregnancy}

Table 5 describes bivariate analysis of the socio-demographic risk factors for adolescent pregnancy. The mean age (SD, Range) was $18(1.1,14-19)$ years for those who had a pregnancy and $16.4(1.9,13-19)$ among those who had never had a pregnancy.

The findings of the bivariate analysis of behaviour and family-related risk factors of adolescent pregnancy are summarized in table 6 below. Knowledge of pregnancy prevention and contraceptive use were statistically significant risk factors of pregnancy.

\section{Multivariate analysis of Risk Factors of Adolescent Pregnancy}

All the variables with $p$ values below 0.2 were put in the model to determine independent predictors of adolescent pregnancy. Factors that are independent predictors of adolescent pregnancy included are summarized in Table 5 below.

\section{Sub-analysis of risk factors of adolescent pregnancy by district}

We conducted a sub analysis by district to find the risk factors of adolescent pregnancy by district. We found some differences as noted in table 6 . In both districts, age and not going to school were risk factors for pregnancy. In Kamuli district, sexual abuse, working for money, "ever-taken alcohol" and accurate knowledge of contraceptives increased the risk. In Wakiso district, "ever wanted to take her life", no education and poverty were risk factors.

\section{Qualitative Findings}

\section{Protective and Risk factors for adolescent pregnancy}

Qualitative findings revealed factors that protect or increase risk of adolescent pregnancy and these are summarized in matrix 1.

\section{Matrix 1: Protective and risk factors for teenage pregnancy}




\begin{tabular}{|c|c|c|}
\hline Level & $\begin{array}{l}\text { Protective factors against } \\
\text { pregnancy }\end{array}$ & Factors increasing pregnancy \\
\hline \multirow[t]{6}{*}{ Individual } & - Being in school & - Inadequate information on SRH \\
\hline & \multirow{2}{*}{$\begin{array}{l}\text { - Having personal goals or } \\
\text { aspirations }\end{array}$} & - Early sexual debut \\
\hline & & - Alcohol and drug abuse \\
\hline & - Access to SRH information & - Being out of school \\
\hline & - Use of family planning & - Older adolescents \\
\hline & - Religion/fear of God & \\
\hline \multirow[t]{8}{*}{ Relationship } & - Good relationship with parents & - Absence of parental supervision \\
\hline & \multirow{2}{*}{$\begin{array}{l}\text { - Parent-adolescent } \\
\text { communication }\end{array}$} & - Disobedient adolescents \\
\hline & & - Negative peer influence \\
\hline & $\begin{array}{l}\text { - Parental guidance and } \\
\text { supervision }\end{array}$ & - Abuse at home/Domestic violence \\
\hline & - Meeting basic needs & - Negative parental influence \\
\hline & - Exemplary parents & \\
\hline & - Positive peer influence & \\
\hline & - Small families & \\
\hline $\begin{array}{l}\text { Community } \\
\text { and }\end{array}$ & $\begin{array}{l}\text { - Community and radio SRH } \\
\text { programs }\end{array}$ & $\begin{array}{l}\text { - Unregulated information in the media (radio, TV, } \\
\text { social media) }\end{array}$ \\
\hline \multirow{6}{*}{$\begin{array}{l}\text { Society } \\
\text { factors }\end{array}$} & - Role models & - Desire for material/monetary gains \\
\hline & \multirow[t]{5}{*}{ - Child protection services } & - Poverty- inability to meet needs \\
\hline & & - Negative community influence and norms \\
\hline & & - slums, acceptance of child marriage \\
\hline & & -Weak legal system \\
\hline & & -Widespread alcohol and drug abuse \\
\hline
\end{tabular}

\section{Protective factors against adolescent pregnancy}

As shown in matrix 1 , the study revealed protective factors at individual, relationship and broader community levels. At individual level, being in school, having personal goals/aspirations, use of contraceptives, access to $\mathrm{SRH}$ information and religion/fear of God were mentioned as key protective factors against adolescent pregnancy. Study participants viewed schools as keeping adolescents busy, offering guidance and counseling and promoting self-esteem and respect that keep adolescent away from engaging in premarital sexual activity thus avoiding becoming pregnant.

When a child is at school, she gets counseling from home and school. She comes back from school late and leaves home early to go to school. All the time she is busy that can help her to protect herself (FGD older out-ofschool adolescents, Wakiso) 
The chances of a girl out-of-school getting pregnant are high. This is because she has nothing to do. But the one in school is kept busy. (FGD older out-of-school-Wakiso)

Most study participants expressed worry of the likely increase in adolescent pregnancies following closure of schools due to COVID-19.

I think you have also heard that during this COVID-19 period when these girls are not in school, we have got more pregnancies. Children don't have anything to do, so nothing else keeps them busy except being sexually active. (KII Peer educator Wakiso)

Having targets or future career aspirations was also mentioned as a protective factor for adolescent pregnancy. I ask my children every time from the youngest, "What are you going to become when you grow up?". You see, you have to keep talking these things to the children. If she is studying to become a health worker you ask her, "Do you know what can stop you from continuing with school? (KII Leader Wakiso)

Access to information on SRH including on pregnancy prevention and having faith in God were other key individual level protective factors.

\section{Relationship level protective factors against adolescent pregnancy}

Study findings revealed that adolescents who had good relationship with parents, received guidance and supervision and had their basic needs met were protected from pregnancy. Parent-adolescent communication including sexual and reproductive health was another protective factor against pregnancy.

Communication has helped put in me a mentality that when I get pregnant, I'm not returning home. This is because whenever my father is counseling me, he tells me, "If you get pregnant you won't see me again...." I love him so much, so this message is ever on my mind. I'm not going to get pregnant (FGD older adolescents out-ofschool, Wakiso)

Parents who provided good examples to their children like not engaging in multiple sexual relationships and not abusing alcohol as well as those who provided for basic needs including sanitary pads were also mentioned as protective factors for adolescents against pregnancy.

If you are at school and you tell your parents that you need knickers, pens and all other stuff and they buy them for you, you will not fall in love just because you know that they are providing you each and everything you need. (IDI pregnant Adolescent Wakiso)

I think that when this adolescent girl has all the necessities she requires, she will not get pregnant because it is lack of money that always puts them in these problems (KII Religious leader, Kamuli)

Small families which enable parents to have adequate time to guide and support children was another protective factor.

In families with few children, they (parents) give time to their adolescents but for those with many children some are sent to the village to their grandparents who might not manage them. The rich usually have three or four 
children who they are able to cater for and also stay with them and they easily monitor them (IDI pregnant adolescent Kamuli)

Having peers with positive influence like encouraging each other to remain in school and to avoid risky behaviours such as use of alcohol and engaging in premarital sex was another protective factor mentioned.

Some adolescents, their friends tell them and keep them safe from getting unwanted pregnancies (IDI pregnant Adolescent, Wakiso)

\section{Community Level Protective factors}

At community level, availability of community support and education programs on $\mathrm{SRH}$, counseling services, having good community role models who educate adolescents about remaining in school and child protection services such as police and probation and welfare officers also help to prevent adolescent pregnancies.

Radio talk shows. The various shows talking about SRH and play skits on radio have helped some adolescents from getting pregnant (KII, CDO Kamuli)

Having good role models like the Queen mother of Buganda, the Speaker of Parliament encouraged adolescent girls to remain in school and avoid becoming pregnant.

\section{Factors increasing the risk of adolescent pregnancy}

At individual level, inadequate information on SRH, early sexual debut, alcohol and drug abuse being out of school especially for older adolescents increased risks of becoming pregnant.

Limited information about SRH. This is making the boy and the girl miss out the basic information about sexual health. They will have it in mind to test and discover what exactly happens when we do what we see and hear (KII Teacher, Kamuli)

Early sexual debut was another driver of adolescent pregnancy mentioned:

Adolescents engage into sexual intercourse early. Here they are very sharp. They start at fourteen to fifteen years .... and remember that if a girl starts menstrual periods and indulges in sex, the end result is being pregnant (IDI Adolescent, Kamuli)

Drug and alcohol abuse and limited judgment were also mentioned as factors leading to adolescent pregnancy.

Our children here take drugs and alcohol. Such children cannot control themselves and end up in sexual activity and become pregnant, (FGD fathers, Wakiso)

At relationship level, absence of parental supervision, disobedient adolescents, negative influence from peers, child abuse and domestic violence as well as negative parental influence were key factors mentioned to increase adolescent pregnancy.

Lack of parental supervision and guidance was mentioned as a factor leading to teenage pregnancy. Study participants mentioned that children who are not well guided or have poor relationships with their parents are 
easily lured into sexual activity.

Negative parental influence such as bringing sexual partners at home and having sex when children are listening can also lead girls into pregnancy.

In most cases, we the mothers are the ones who spoil our children ... By bringing in many men, one goes out (a man) and the next one (another man) comes in then you are spoiling the children. (FGD Mothers, Wakiso)

In small houses at night, a child will listen to what you are doing and she will also go and discuss it with her friends. In the end, they will also end up going to demonstrate what father and mother does. (IDI Adolescent, Kamuli)

Other parents stay with their children, so they play sex when children are hearing. So, the next day the children may want to do it (KII District Official, Kamuli)

It was noted that some girls engage in sexual relationships to escape mistreatment at home.

Mistreatment at home is obvious case. You'll definitely decide one day and run away from home to go and find a way to survive and that's where you'll get problems, boys or maybe your friends may connect you to boyfriends. (FGD older adolescents out-of-school Kamuli)

At home they might mistreat me but if I have boy who loves me and says that he wants to marry me, why should I stay at home when I'm being mistreated? (FGD younger adolescents in-school, Wakiso)

Child abuse especially sexual abuse was also linked to increased cases of adolescent pregnancy.

Sometimes she's raped or parents force her against her will when they want finances (FGD younger adolescent in school, Wakiso)

Some study participants blamed girls for dressing inappropriately as reason for sexual abuse.

Negative influence of peers and parents were also mentioned as factors leading to adolescent pregnancy. It was noted that some girls are encouraged by their peers or parents to get into sexual relationships in anticipation of material or monetary gifts. Others become pregnant owing to negative influence from their peers.

You can find your friend having a nice skirt but when you have no way you can have it. When you go to her and consult where she bought her nice skirt, she says she fell in love and then got it. You also end up doing the same and then get pregnant. (IDI Pregnant Adolescent, Kamuli)

I could be with my friends and they share what they do with their boyfriends. One can tell you that they had fun and drunk (alcohol). This gives you ideas and you tell your boyfriend to do the same and the end result is pregnancy (FGD Adolescents in school Wakiso)

At broader community level, unregulated information in the media (radio, TV, social media), desire for material/monetary gains among adolescents, poverty and inability to meet basic needs, negative community influence and norms such as acceptance of child marriage, widespread use of alcohol and drugs especially in 
slums and the weak legal and child protection systems were key drivers of adolescent pregnancy in the study setting.

Most study participants attributed the high rates of adolescent pregnancy to unregulated print and electronic media content that makes sexual activity attractive for young people and some try it out and become pregnant.

You see even those films are vulgar (pornographic)... A child may see a film that has sexual intercourse scenes in it and says that let me also try it out and she gets pregnant (FGD older adolescents out of school Wakiso)

Then in the urban set-up the radios, televisions and phones cause a lot of destruction... (KII Wakiso District leader)

Desire for quick monetary and material gains among adolescent girls led to sexual relationships with older men who can provide such and girls ended becoming pregnant. For some of hem it is due to poverty.

Just buying some food will entice a girl into sex. They admire some small things like "kicomando"(cheap food sold on the roadside). Because the parents can't afford giving the required necessities to their children (IDI

Adolescent, Wakiso)

\section{Discussion}

This study sought to determine risk factors for adolescent pregnancy among adolescent girls in one rural and one urban district in Uganda. We found an increased risk of pregnancy amongst older adolescents, and those who were out of school. This is likely because while they are in school, they are very engaged, receive guidance from school teachers and have a clear reason to avoid pregnancy. Those who are ot-of-school are usually very poor and the increased needs coupled with little access to contraceptives predisposes them to pregnancy. Poverty has been noted to predispose to adolescent pregnancy (Tabei K et al., 2021). Several studies included in systematic reviews have demonstrated that keeping adolescents in school is protective against adolescent pregnancy (Kassa GM, Arowojolu AO, Odukogbe AA, Yalew AW, 2018; Pradhan R et al., 2015).

Other independent risk factors for adolescent pregnancy identified by the study included having ever smoked and having a friend who had ever been pregnant. This reflects high risky behaviour and peer influence which are both characteristic of the adolescent period. Risky behaviour and peer pressure have been reported in a recent systematic review (Chung HW et al., 2018). In a review of literature from Africa, having peers who had gone through pregnancy was a risk for repeat adolescent pregnancy (Govender D et al., 2018). Ochen et al also found that adolescents who reported experiences of intense peer pressure and taking alcohol had an increased likelihood of adolescent pregnancy (Ochen AM \& Chi PC, Lawoko S, 2019). Adolescents are likely to be influenced by their peers and take the practices of those around them therefore this finding is not surprising.

Having accurate knowledge on contraceptives increased the risk of pregnancy. This was a surprising finding. However, a recent study indicated the same finding (Tabei K et al., 2021) It indicates that knowledge alone is not enough to prevent pregnancy among adolescents. It is also possible that they acquired the knowledge after getting pregnant. 
Maternal education has also been found to influence the outcomes of children in particular adolescent pregnancy (Kassa GM, Arowojolu AO, Odukogbe AA, Yalew AW, 2018). In fact it has been shown that where mothers had a pregnancy before the age of 19 years this increases the risk of adolescent pregnancy for their daughters (Wall-Wieler E et al., 2016).

Living in a household size of 4-8 was found to be protective against adolescent pregnancy in comparison to smaller households. This is contrary to what has been reported in literature. (Tabei K et al., 2021). In our study, it is possible that the small families were those where adolescents were "married" with one child, making it a small household.

Good personal attitudes or self-efficacy were protective against adolescent pregnancy. These adolescents believed it was not difficult for them to avoid a pregnancy. Good personal attitudes empower the adolescent to bargain and defend herself based on her belief system. This will protect her from the potential predators and gives girls an upper hand to decide when to have sex, practicing protected sex and making decisions about using contraceptives. A recent study in Lagos among in-school adolescent girls reports that future orientation significantly influenced safe sex self-efficacy (Nwaozuru U et al., 2020).

Kamuli district in Eastern Uganda is predominantly a rural and poor population. Among the study population in Kamuli district, we found additional risk factors for adolescent pregnancy including: having been sexually abused, reported use of alcohol and engaging in work for money. Evidence suggests that adolescents living in rural settings are at higher risk of pregnancy compared to those living in urban settings (Kassa GM, Arowojolu AO, Odukogbe AA, Yalew AW, 2018). This may be due to the effect of poverty in rural community. Sexual abuse and alcohol abuse are common in these settings that are poverty stricken.

In contrast, we found that amongst the adolescents in Wakiso district which is urban or peri-urban setting, those who had ever wanted to take their lives had a higher risk of teenage pregnancy. Depression and suicidal ideation have been shown to increase the risk of repeat adolescent pregnancy (Govender D et al., 2018). In Wakiso, coming from a rich family was protective against teenage pregnancy which was not in the rural setting. In urban areas, there is a clear difference in lifestyle and practices between the rich and the poor which may not be apparent in rural areas. Lower socio-economic status has also been found to be a risk factor for adolescent pregnancy (Govender D et al., 2018).

Furthermore, having discussed sex with one's parent/guardian, feeling safe while at home and good personal attitude were protective factors against pregnancy. Discussing matters regarding to sex between parents and adolescents has been found to be rare in Uganda and where this happens the discussion is likely to be unidirectional as opposed to open dialogue (Muhwezi WW et al., 2015). Discussing sex with the parents empowers the adolescent with information on pregnancy prevention (Chung HW et al., 2018).

The strength of this study is that it employed both qualitative and quantitative methods of data collection. In addition, we captured data from adolescents, their parents, health workers, school teachers and other stakeholders.

Overall, factors like older age, not going to school, low education of father, smaller household size, negative personal attitudes and accurate knowledge of contraceptives increased the risk of adolescent pregnancy among both urban and rural residing adolescents although the magnitude differs.

Page $14 / 27$ 
For the rural adolescents, sexual abuse, working for money and alcohol use increased the risk of pregnancy while feeling safe and having positive personal attitudes were protective. For the adolescents in Wakiso, higher level of education and being rich were protective while depression was a risk factor for pregnancy.

In addition, qualitative findings highlighted that having future goals and aspirations, good relationship with parents, positive peer influence and having role models as protective factors while early sex debut, inadequate information on SRH, limited parental supervision and support, negative peer influence, mistreatment and abuse are risk factors. In addition, unregulated media content, poverty and desire for monetary and material gains as key factors increasing risk to adolescent pregnancy in the two study districts.

We recommend that efforts to keep girls in school and to reduce poverty should continue since they are key in prevention of adolescent pregnancy. In addition, more support is needed to adolescents to improve their positive personal attitudes since it was protective in all adolescents. Contraceptive knowledge alone is not enough to prevent adolescent pregnancy. It has to go along with enforcing positive attitudes and self-efficacy among the adolescents. Furthermore, interventions to prevent adolescent pregnancy should be specific to the residence of adolescents. Rural dwelling adolescents have unique needs when compared to the urban-dwelling adolescents. More research is needed to explore why accurate contraceptive knowledge was associated with adolescent pregnancy

\section{Declarations}

\section{Availability of data}

All the data supporting our findings is available on request from the corresponding author.

\section{Funding}

The research was funded by the Government of Uganda through Makerere Research and Innovation fund.

\section{Authors' contributions}

All the authors contributed to conception of the study. PM analyzed the quantitative data while JR analyzed the qualitative data. NNB drafted the first manuscript and all authors contributed and approved the final draft.

\section{Acknowledgements}

We would like to acknowledge all the adolescents and their parents/guardians who took part in this study. The research participants who participated in the data collection. The district health team at Kamuli and Wakiso districts who introduced us to the community is highly appreciated.

None of the authors have any competing interests to declare.

\section{References}


1. Chung HW, Kim EM, \& Lee JE. (2018). Comprehensive understanding of risk and protective factors related to adolescent pregnancy in low- and middle-income countries: A systematic review. 69, 180-188. https://doi.org/10.1016/j.adolescence.2018.10.007

2. Filmer D, \& Pritchett LH, last. (2011). “Estimating Wealth Effect Without Expenditure Data or Tears: An Application to Educational Enrollments in States of India.". 38, 115-132.

3. Govender D, Naidoo S, \& Taylor M. (2018). Scoping review of risk factors of and interventions for adolescent repeat pregnancies: A public health perspective. 10(1), e1-e10.

4. Graneheim UH, \& Lundman B. (2004). Qualitative content analysis in nursing research: Concepts, procedures and measures to achieve trustworthiness. 24(2), 105-112.

5. Kassa GM, Arowojolu AO, Odukogbe AA, Yalew AW. (2018). Prevalence and determinants of adolescent pregnancy in Africa: A systematic review and Meta-analysis. 15(1):195(1), 195.

6. MoH, Uganda. (2016). Investment Case for Reproductive, Maternal, Newborn, Child and Adolescent Health. Shapened Plan for Uganda 2016/17 - 2019/20.

7. Mpyangu CM, O. A., Onyango OE, \&. Lubaale MY. (2014). Out of school children study in Uganda. UNICEF. https://www.unicef.org/uganda/OUT_OF_SCHOOL_CHILDREN_STUDY_REPORT_FINAL_REPORT_2014.pdf

8. Muhwezi WW, Katahoire AR, Banura C, Mugooda H, \& Klepp KI. (2015). Perceptions and experiences of adolescents, parents and school administrators regarding adolescent-parent communication on sexual and reproductive health issues in urban and rural Uganda. 12, 110. https://doi.org/10.1186/s12978-015-0099-3

9. Nwaozuru U, Blackstone S, Obiezu-Umeh C, \& Iwelunmor J. (2020). Psychosocial correlates of safe sex selfefficacy among in-school adolescent girls in Lagos, Nigeria. 15(6), e0234788. https://doi.org/10.1371/journal.pone.0234788

10. Ochen AM, \& Chi PC, Lawoko S. (2019). Predictors of teenage pregnancy among girls aged 13-19 years in Uganda: A community based case-control study. 19(1), 211.

11. Pradhan R, Wynter K, \& Fisher J. (2015). Factors associated with pregnancy among adolescents in lowincome and lower middle-income countries: A systematic review. 69(9), 918.

12. Sallis JF, Owen N, \& Fisher E. (2015). Ecological models of health behavior. 5, 43-64.

13. Stokols D. (1996). Translating social ecological theory into guidelines for community health promotion. 10(4), 282-298. https://doi.org/10.4278/0890-1171-10.4.282 PMID: 10159709

14. Tabei K, Cuisia-Cruz E, \& Seposo X. (2021). Association between Teenage Pregnancy and Family Factors: An Analysis of the Philippine National Demographic and Health Survey 2017. 9(12), 1720. https://doi.org/10.3390/healthcare9121720

15. Tuyiragize R, N., A. ,. Asiimwe, J. B. ,. Kakuba, C. ,. Mushomi, J. ,. \&. Maniragaba, F. (2018). Predisposing factors of teenage pregnancy in the Uganda Lake Victoria Island and Mountain districts. https://doi.org/10.1101/482927

16. UBOS. (2012). Uganda demographic and health survey 2011 (Bur Stat ICF Int Inc). www.ubos.org/onlinefiles/uploads/ubos/UDHS/UDHS2011.pdf

17. UBOS. (2014). National population and housing census 2014 revised edition.

18. UBOS, I. (2017). Uganda demographic and health survey 2016 Key Indicators Report. www.ubos.org/onlinefiles/uploads/ubos/UDHS/UDHS2011.pdf 
19. Wall-Wieler E, Roos LL, \& Nickel NC. (2016). Teenage pregnancy: The impact of maternal adolescent childbearing and older sister's teenage pregnancy on a younger sister. 16, 120.

https://doi.org/10.1186/s12884-016-0911-2

20. WHO. (2014). Adolescent pregnancy: Adolescence is a time of opportunity during which a range of actions can be taken to set the stage for healthy adulthood: Fact sheet (No. WHO/RHR/14.08). World Health Organization.

21. Yakubu I, \& Salisu WJ. (2018). Determinants of adolescent pregnancy in sub-Saharan Africa: A systematic review. Reproductive health. 2018;15(1):15. 15(1), 15.

\section{Tables}

Table 1: Socio-demographic Characteristics of adolescent surveyed $(n=600)$ 


\begin{tabular}{|c|c|c|c|}
\hline \multirow[t]{3}{*}{ Age (years) } & $13-14$ & 85 & 15.3 \\
\hline & $15-16$ & 125 & 21.3 \\
\hline & $17-19$ & 390 & 63.3 \\
\hline \multirow[t]{3}{*}{ Marital status } & $\begin{array}{l}\text { Single - not in } \\
\text { relationship }\end{array}$ & 340 & 57.6 \\
\hline & Single - in a relationship & 175 & 32.7 \\
\hline & Married/separated & 85 & 9.7 \\
\hline \multirow{3}{*}{$\begin{array}{l}\text { Highest level of education completed } \\
(n=586)^{* \star}\end{array}$} & None & 153 & 34.4 \\
\hline & Primary & 310 & 53.0 \\
\hline & Secondary and above & 123 & 12.5 \\
\hline School going & Yes & 430 & 75.3 \\
\hline \multirow[t]{5}{*}{ Religion } & Catholics & 170 & 19.4 \\
\hline & Anglican & 196 & 39.3 \\
\hline & Pentecostal & 90 & 15.7 \\
\hline & Muslim & 137 & 24.3 \\
\hline & Other & 7 & 1.3 \\
\hline \multirow[t]{4}{*}{ Orphanhood status } & Both parents alive & 459 & 77.0 \\
\hline & Both parents dead & 22 & 2.7 \\
\hline & Only mother alive & 81 & 15.0 \\
\hline & Only father alive & 38 & 5.3 \\
\hline \multirow[t]{2}{*}{ Disability status } & Yes & 48 & 11.0 \\
\hline & No & 552 & 89.0 \\
\hline \multirow[t]{4}{*}{ Form of disability $(n=48)$} & Physical & 21 & 58.0 \\
\hline & Visual & 19 & 45.1 \\
\hline & Hearing/Speech & 18 & 45.1 \\
\hline & Multiple ( $\geq 2$ forms) & 12 & 4.0 \\
\hline \multirow[t]{3}{*}{ Relationship to household head } & Spouse/Partner & 83 & 9.3 \\
\hline & Daughter & 401 & 76.6 \\
\hline & Other relatives & 116 & 14.0 \\
\hline
\end{tabular}


** Highest level completed - None - not sat PLE or never gone to school, Primary - attained PLE certificate, secondary - attained UCE.

Table 2: Behaviour and experiences of the 600 adolescents

\begin{tabular}{|c|c|c|c|}
\hline Covariates & & Frequency & Weighted percentage \\
\hline Ever had sex & & 337 & 62.3 \\
\hline Consented to sex $(\mathrm{N}=337)$ & & 300 & 89.3 \\
\hline Used a condom ( $\mathrm{N}=337)$ & & 139 & 47 \\
\hline Reports being physically abused & & 116 & 16.7 \\
\hline Reports Sexual abuse & & 39 & 4.3 \\
\hline Has a friend who has ever got pregnant & & 339 & 56.0 \\
\hline Ever tested for HIV & & 323 & 54.0 \\
\hline Ever used contraceptives & & 106 & 21.0 \\
\hline Has a friend who uses drugs/alcohol/smoke & & 105 & 12.3 \\
\hline Ever taken alcohol & & 60 & 5.3 \\
\hline Ever smoked cigarettes & & 8 & 1.3 \\
\hline Ever used drugs & & 7 & 1.3 \\
\hline Have Freedom to clubs/dances & & 95 & 15.7 \\
\hline Ever attempted to take own life & & 153 & 26.3 \\
\hline Feels safe at home & & 495 & 81.0 \\
\hline Ever missed school due to menstruation & & 201 & 46.0 \\
\hline What is used during menstruation $(n=579)$ & Pads & 474 & 81.9 \\
\hline & Cloths & 100 & 17.2 \\
\hline & Cotton & 5 & 0.9 \\
\hline Does some work for money & & 131 & 17.0 \\
\hline
\end{tabular}

Table 3: Bivariate analysis of Socio-demographic Risk Factors for adolescent pregnancy 


\begin{tabular}{|c|c|c|c|c|c|}
\hline Characteristic & & $\begin{array}{l}\text { Currently } \\
\text { pregnant } \mathrm{N}=200\end{array}$ & $\begin{array}{l}\text { Never been } \\
\text { pregnant } \mathrm{N}=400\end{array}$ & $\begin{array}{l}\text { Chi- } \\
\text { square }\end{array}$ & $\mathrm{p}$-value \\
\hline \multirow[t]{3}{*}{ Age group (years) } & $13-14$ & 1.0 & 20.7 & 91.63 & $<0.001^{*}$ \\
\hline & $15-16$ & 8.0 & 27.3 & & \\
\hline & $17-19$ & 91.0 & 52.0 & & \\
\hline \multirow[t]{3}{*}{ Marital status } & $\begin{array}{l}\text { Single - not in } \\
\text { relationship }\end{array}$ & 30.5 & 69.7 & 143.38 & $<0.001^{*}$ \\
\hline & $\begin{array}{l}\text { Single - in a } \\
\text { relationship }\end{array}$ & 33.0 & 27.2 & & \\
\hline & Married/separated & 36.5 & 3.0 & & \\
\hline \multirow{3}{*}{$\begin{array}{l}\text { Highest education } \\
\text { completed }(n=586)\end{array}$} & None & 31.1 & 23.6 & 3.86 & 0.145 \\
\hline & Primary & 49.0 & 54.9 & & \\
\hline & $\begin{array}{l}\text { Secondary and } \\
\text { above }\end{array}$ & 19.9 & 21.5 & & \\
\hline In school $(n=547)$ & Yes & 52.7 & 89.8 & 94.13 & $<0.001^{\star}$ \\
\hline \multirow[t]{5}{*}{ Religion } & Catholic & 29.5 & 27.7 & 2.32 & 0.721 \\
\hline & Anglican & 30.0 & 34.0 & & \\
\hline & Pentecostal & 16.0 & 14.5 & & \\
\hline & Muslim & 24.0 & 22.2 & & \\
\hline & Other & 0.5 & 1.5 & & \\
\hline \multirow[t]{4}{*}{ Orphan hood status } & Both parents alive & 69.0 & 80.2 & 10.07 & $0.018 * *$ \\
\hline & Both parents' dead & 4.0 & 3.5 & & \\
\hline & Only mother alive & 18.5 & 11.0 & & \\
\hline & Only father alive & 8.5 & 5.2 & & \\
\hline \multirow[t]{2}{*}{ Disability status } & Yes & 8.0 & 8.0 & 0.00 & 1.000 \\
\hline & No & 92.0 & 92.0 & & \\
\hline \multirow{5}{*}{$\begin{array}{l}\text { Fathers highest level of } \\
\text { education }\end{array}$} & None & 20.0 & 17.5 & 17.59 & $0.001 *$ \\
\hline & Primary & 20.0 & 14.7 & & \\
\hline & O'Level & 9.0 & 13.5 & & \\
\hline & A'level+ & 6.5 & 17.0 & & \\
\hline & Don't know & 44.5 & 37.2 & & \\
\hline \multirow{2}{*}{$\begin{array}{l}\text { Mother's highest level of } \\
\text { education }\end{array}$} & None & 25.0 & 23.0 & 6.22 & 0.183 \\
\hline & Primary & 24.0 & 19.7 & & \\
\hline
\end{tabular}




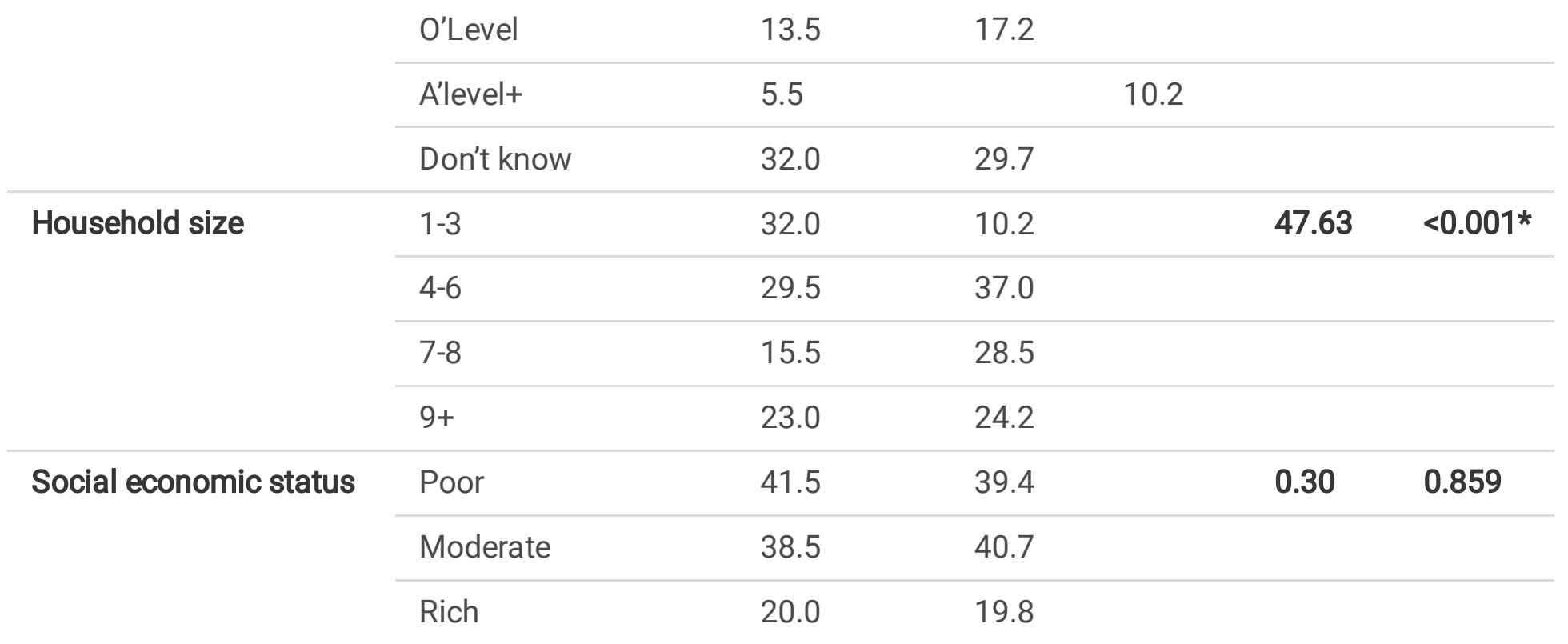

Table 4: Bivariate analysis of Family and Behaviour Risk factors for adolescent pregnancy 


\section{Characteristic}

Parents are

separated/divorced

\begin{tabular}{|c|c|c|c|c|c|}
\hline & 63.5 & & 72.0 & & \\
\hline \multirow[t]{4}{*}{ Parenting style } & Disciplinarian/Authoritarian & 35.0 & 42.5 & 5.71 & 0.127 \\
\hline & Permissive or liberal & 42.5 & 41.0 & & \\
\hline & Uninvolved & 9.0 & 8.2 & & \\
\hline & Others & 13.5 & 8.2 & & \\
\hline \multirow[t]{3}{*}{ Parent drink alcohol } & Yes & 26.0 & 18.7 & 4.35 & 0.118 \\
\hline & No & 72.0 & 78.5 & & \\
\hline & Don't know & 2.0 & 2.7 & & \\
\hline \multirow[t]{2}{*}{ Sexual abuse } & Yes & 9.0 & 5.2 & 3.08 & 0.079 \\
\hline & No & 91.0 & 94.7 & & \\
\hline \multirow[t]{2}{*}{ History of mental illness } & Yes & 5.5 & 2.7 & 2.85 & 0.091 \\
\hline & No & 94.5 & 97.3 & & \\
\hline \multirow{2}{*}{$\begin{array}{l}\text { Discussed sex with a } \\
\text { parent }\end{array}$} & Yes & 51.5 & 44.7 & 2.44 & 0.118 \\
\hline & No & 48.5 & 55.2 & & \\
\hline \multirow{2}{*}{$\begin{array}{l}\text { A friend who has ever got } \\
\text { pregnant }\end{array}$} & Yes & 75.0 & 47.3 & 41.78 & $<0.001^{*}$ \\
\hline & No & 25.0 & 52.7 & & \\
\hline \multirow[t]{2}{*}{ Ever used contraceptives } & Yes & 34.5 & 9.2 & 58.44 & $<0.001^{*}$ \\
\hline & No & 65.5 & 90.7 & & \\
\hline \multirow{2}{*}{$\begin{array}{l}\text { Friend who use } \\
\text { drugs/alcohol/smoke }\end{array}$} & Yes & 20.0 & 16.3 & 1.29 & 0.254 \\
\hline & No & 80.0 & 83.7 & & \\
\hline \multirow[t]{2}{*}{ Ever taken alcohol } & Yes & 14.0 & 8.0 & 5.33 & 0.021 ** \\
\hline & No & 86.0 & 92.0 & & \\
\hline \multirow[t]{2}{*}{ Ever smoked cigarettes } & Yes & 3.0 & 0.5 & 6.33 & $0.019 * *$ \\
\hline & No & 97.0 & 99.5 & & \\
\hline Used drugs before & Yes & 2.5 & 0.5 & 4.62 & $0.044^{*}$ \\
\hline
\end{tabular}

\section{Currently Never Chi-square p-value \\ $\mathrm{N}=\mathbf{2 0 0}$ \\ pregnant \\ $\mathrm{N}=400$}

28.0

4.52

0.032

36.5

72.0

41.0

8.2

4.35

0.118

72.0

2.7

9.0

5.2

94.7

5.5

2.7

2.85

0.091

55.2

75.0

47.3

41.78

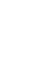




\begin{tabular}{|c|c|c|c|c|c|}
\hline & No & 97.5 & 99.5 & & \\
\hline \multirow[t]{2}{*}{ Freedom to club/dance } & Yes & 21.5 & 13.0 & 7.23 & $0.007^{\star}$ \\
\hline & No & 78.5 & 87.0 & & \\
\hline \multirow[t]{2}{*}{ Feels Safe at home } & Yes & 79.5 & 84.0 & 1.87 & 0.171 \\
\hline & No & 20.5 & 16.0 & & \\
\hline \multirow[t]{2}{*}{ Owns mobile phone } & Yes & 52.0 & 29.0 & 30.37 & $<0.001 *$ \\
\hline & No & 48.0 & 71.0 & & \\
\hline \multirow[t]{2}{*}{ Used pornography } & Yes & 61.5 & 45.5 & 13.66 & $<0.001^{*}$ \\
\hline & No & 38.5 & 54.5 & & \\
\hline \multirow{2}{*}{ Works for money } & Yes & 31.5 & 17.0 & 16.42 & $<0.001^{*}$ \\
\hline & No & 68.5 & 83.0 & & \\
\hline $\begin{array}{l}\text { Knowledge of pregnancy } \\
\text { prevention }\end{array}$ & & $5.2(1.2)$ & $4.8(1.3)$ & -2.99 & $0.003^{*}$ \\
\hline $\begin{array}{l}\text { Knowledge of avoiding } \\
\text { STIs }\end{array}$ & & $7.8(1.7)$ & $7.7(1.7)$ & -0.07 & 0.939 \\
\hline $\begin{array}{l}\text { Knowledge relating to } \\
\text { puberty }\end{array}$ & & $5.8(1.8)$ & $5.9(1.8)$ & 0.65 & 0.516 \\
\hline Positive personal attitudes & & $3.9(1.6)$ & $4.4(1.5)$ & 4.39 & $<0.001^{*}$ \\
\hline $\begin{array}{l}\text { Knowledge on } \\
\text { contraceptive use }\end{array}$ & & $3.3(1.3)$ & $2.7(1.3)$ & -5.42 & $<0.001 *$ \\
\hline $\begin{array}{l}\text { Accuracy of SRH } \\
\text { information }\end{array}$ & & $\begin{array}{l}10.1 \\
(1.5)\end{array}$ & $10.0(1.7)$ & -0.33 & 0.739 \\
\hline
\end{tabular}

Table 5: Multivariable logistic model for risk factors of adolescent pregnancy 


\begin{tabular}{|c|c|c|c|}
\hline Risk factor & & Crude OR $(95 \% \mathrm{Cl})$ & $\begin{array}{l}\text { Adjusted OR } \\
(95 \% \mathrm{Cl})\end{array}$ \\
\hline Age & & $1.91(1.68-2.16)$ * & $\begin{array}{l}1.65(1.44- \\
1.91) \star \star \star\end{array}$ \\
\hline \multirow{3}{*}{$\begin{array}{l}\text { Highest education completed } \\
(\mathrm{n}=586)\end{array}$} & None & $1.42(0.86-2.35)$ & \\
\hline & Primary & $0.96(0.62-1.52)$ & \\
\hline & Primary+ & 1 & \\
\hline \multirow[t]{2}{*}{ Currently in school } & Yes & 1 & 1 \\
\hline & No & $\begin{array}{l}7.89(5.02- \\
12.38) \star \star \star\end{array}$ & $\begin{array}{l}4.42(2.57- \\
7.60) * \star \star\end{array}$ \\
\hline \multirow[t]{4}{*}{ Orphan hood status } & Both parents alive & 1 & \\
\hline & Both parents' dead & $1.32(0.54-3.24)$ & \\
\hline & Only mother alive & ${ }_{\star \star}^{1.95}(1.21-3.16)$ & \\
\hline & Only father alive & ${ }_{\star \star \star \star}^{1.88}(0.96-3.68)$ & \\
\hline \multirow[t]{5}{*}{$\begin{array}{l}\text { Fathers highest level of } \\
\text { education }\end{array}$} & None & $\underset{\star \star}{2.98}(1.47-6.08)$ & $\begin{array}{l}3.06(1.36- \\
6.87) \star \star\end{array}$ \\
\hline & Primary & $\underset{\star \star}{3.55}(1.73-7.26)$ & $\begin{array}{l}4.14(1.73- \\
9.89) \star \star\end{array}$ \\
\hline & O’Level & $1.74(0.78-3.87)$ & $\begin{array}{l}1.79(0.69- \\
4.61)\end{array}$ \\
\hline & A'level+ & 1 & 1 \\
\hline & Don't know & $\underset{\star \star}{3.12}(1.63-5.98)$ & $\begin{array}{l}2.96(1.36- \\
6.42) \star \star\end{array}$ \\
\hline \multirow[t]{5}{*}{$\begin{array}{l}\text { Mother's highest level of } \\
\text { education }\end{array}$} & None & $2.02(0.95-4.29)$ & \\
\hline & Primary & $2.26(1.06-4.83)$ & \\
\hline & O'Level & $\begin{array}{l}1.46(0.65- \\
3.24)\end{array}$ & \\
\hline & A'level+ & 1 & \\
\hline & Don't know & $\underset{\star \star \star}{2.0}(0.96-4.17)$ & \\
\hline \multirow[t]{3}{*}{ Household size } & $1-3$ & 1 & 1 \\
\hline & $4-6$ & $\underset{\star}{0.25}(0.15-0.42)$ & $\begin{array}{l}0.48(0.24- \\
0.96) \star \star\end{array}$ \\
\hline & $7-8$ & $0.17(0.09-0.30)$ & $0.35(0.17-$ \\
\hline
\end{tabular}

Page 24/ 27 


\begin{tabular}{|c|c|c|c|}
\hline & & * & $0.70) * \star$ \\
\hline & $9+$ & $\underset{\star}{0.30}(0.18-0.51)$ & $\begin{array}{l}0.61(0.30- \\
1.25)\end{array}$ \\
\hline \multirow[t]{2}{*}{ Parents are separated/divorced } & No & 1 & \\
\hline & Yes & ${ }_{\star \star}^{1.47}(1.02-2.12)$ & \\
\hline \multirow[t]{4}{*}{ Parenting style } & Disciplinarian/Authoritarian & 1 & \\
\hline & Permissive or liberal & $\begin{array}{l}1.26(0.85- \\
1.84)\end{array}$ & \\
\hline & Uninvolved & $\begin{array}{l}1.32(0.699- \\
2.51)\end{array}$ & \\
\hline & Others & ${ }_{\star \star}^{1.98}(1.11-3.55)$ & \\
\hline \multirow[t]{3}{*}{ Parent drink alcohol } & No & 1 & \\
\hline & Yes & ${ }_{\star \star}^{1.51}(1.01-2.27)$ & \\
\hline & Don't know & $\begin{array}{l}0.79(0.25- \\
2.53)\end{array}$ & \\
\hline \multirow[t]{2}{*}{ Sexual abuse } & No & 1 & \\
\hline & Yes & $\underset{\star \star \star \star}{1.78}(0.93-3.43)$ & \\
\hline \multirow{2}{*}{$\begin{array}{l}\text { History of mental illness } \\
\text { (parents) }\end{array}$} & No & 1 & \\
\hline & Yes & $\underset{\star \star \star}{2.06}(0.87-4.83)$ & \\
\hline \multirow[t]{2}{*}{ Discussed sex with a parent } & No & 1 & \\
\hline & Yes & $\begin{array}{l}1.31(0.93- \\
1.84)\end{array}$ & \\
\hline \multirow{2}{*}{$\begin{array}{l}\text { A friend who has ever got } \\
\text { pregnant }\end{array}$} & No & 1 & \\
\hline & Yes & $3.35(2.30-4.87)$ & \\
\hline \multirow[t]{2}{*}{ Ever used contraceptives } & No & 1 & \\
\hline & Yes & ${ }_{*}^{5.17}(3.30-8.08)$ & \\
\hline \multirow[t]{2}{*}{ Ever taken alcohol } & No & 1 & \\
\hline & Yes & $\underset{\star \star}{1.87}(1.09-3.21)$ & \\
\hline Ever smoked cigarettes & No & 1 & 1 \\
\hline
\end{tabular}




\begin{tabular}{|c|c|c|c|}
\hline & Yes & $\begin{array}{l}6.15(1.23- \\
30.81) * *\end{array}$ & $\begin{array}{l}6.16(1.51- \\
25.13) \text { ** }\end{array}$ \\
\hline \multirow[t]{2}{*}{ Used drugs before } & No & 1 & \\
\hline & Yes & $\begin{array}{l}5.10(0.97- \\
26.57) \star \star \star \star\end{array}$ & \\
\hline \multirow[t]{2}{*}{ Freedom to club/dance } & No & 1 & \\
\hline & Yes & ${ }_{\star \star}^{1.83}(1.17-2.86)$ & \\
\hline \multirow[t]{2}{*}{ Safe at home } & No & 1 & \\
\hline & Yes & $\begin{array}{l}0.74(0.47- \\
1.14)\end{array}$ & \\
\hline \multirow[t]{2}{*}{ Ownership of mobile phone } & No & 1 & \\
\hline & Yes & ${ }_{*}^{2.65}(1.86-3.77)$ & \\
\hline \multirow[t]{2}{*}{ Ever used pornographic materials } & No & 1 & \\
\hline & Yes & ${ }_{\star}^{1.91}(1.35-2.71)$ & \\
\hline \multirow[t]{2}{*}{ Works for money } & No & 1 & \\
\hline & Yes & $\underset{\star \star}{2.24}(1.51-3.33)$ & \\
\hline \multicolumn{2}{|c|}{ Correct Knowledge of pregnancy prevention } & $\underset{\star \star}{1.23}(1.07-1.42)$ & \\
\hline \multicolumn{2}{|l|}{ Positive personal attitudes } & $\underset{\star}{0.78}(0.69-0.87)$ & $\begin{array}{l}0.85(0.73- \\
0.99) \star \star\end{array}$ \\
\hline \multicolumn{2}{|c|}{ Correct Knowledge on contraceptive use } & $\frac{1.45(1.26-1.66)}{*}$ & $\begin{array}{l}1.29(1.08- \\
1.53)^{*}\end{array}$ \\
\hline \multicolumn{2}{|c|}{$\mathrm{N}=547$, Pearson chi2 $(491)=426.83, \mathrm{p}-\mathrm{value}=0.983$} & & \\
\hline
\end{tabular}

*** $p<0.001, * \star p<0.05, * p<0.10$

Table 6: Multivariate analysis of Predictors of adolescent pregnancy by district 


\begin{tabular}{|c|c|c|c|}
\hline \multirow[t]{2}{*}{ Characteristic } & \multirow[t]{2}{*}{ Characteristic } & Kamuli & Wakiso \\
\hline & & Adjusted OR (95\%Cl) & Adjusted OR (95\%Cl) \\
\hline Age & & $1.71(1.40-2.07) * \star \star$ & $2.12(1.66-2.71) * \star \star$ \\
\hline Not going to school & & 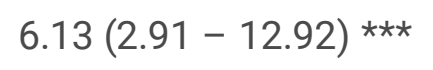 & $2.27(1.01-5.10) * \star$ \\
\hline Sexual abuse & & $4.09(1.52-10.99)$ ** & \\
\hline Ever taken alcohol & & $3.19(1.16-8.81) * \star$ & \\
\hline Feels safe at home & & $0.42(0.18-0.99) * \star$ & \\
\hline Works to get some money & & 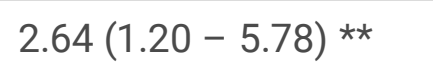 & \\
\hline Positive personal attitudes & & $0.76(0.61-0.94) * \star$ & \\
\hline Accurate Knowledge on contraceptives & & $1.31(1.00-1.71) * \star$ & \\
\hline \multirow[t]{3}{*}{ Highest level of education completed } & None & & 1 \\
\hline & Primary & & $0.311(0.12-0.80)$ ** \\
\hline & Primary+ & & $0.13(0.04-0.42) * \star$ \\
\hline \multirow[t]{3}{*}{ Social economic status } & Poor & & 1 \\
\hline & Moderate & & $0.77(0.35-1.68)$ \\
\hline & Rich & & $0.28(0.09-0.84) * \star$ \\
\hline \multirow[t]{2}{*}{ Ever wanted to take own life } & Yes & & 1 \\
\hline & No & & $3.07(1.42-6.64) * \star \star$ \\
\hline
\end{tabular}

